\title{
Social Ecology and The Growth Machine Coalition in The Surabaya Policy Dilemma
}

\author{
Siti Aminah ${ }^{1}$, A.Hesti Susanti ${ }^{2}$, Roikan ${ }^{3}$ \\ ${ }^{1}$ Department of Political Science, FISIP Airlangga University, Surabaya \\ ${ }^{2}$ CSWS-FISIP Airlangga University, Surabaya \\ ${ }^{3}$ CSWS-FISIP Airlangga University, Surabaya
}

\author{
Article History \\ Received : 11 July 2018 \\ Accepted : 24 January 2019 \\ Published : 01 April 2018
}

\begin{abstract}
This study integrates theoretical and analytical approaches of social ecology, urban growth machine, and urban governments. The aim is to explain forms of contrast collaboration between government (political elite) and private developers (local businesses). Political elite rests on the ideological commitment to collaborate within local individual authorities who see the growth of a city led by the market. City governments work in relatively independent and informal networks that rely on local government bureaucratic structures. The practice of government and private coalition faces social ecology challenges. The development of a city not only creates new economic growth area (within the corridors of independent city's development) but also generates centers of the social ecology crisis. This study uses qualitative methods and takes the form of case studies. Research results show that the operation of the urban growth machine run by the Surabaya government and the private economic power (developers) have not merely carried out sustainable development, produced various advancements for the city and its population but caused losses to the group that let go of their soil (land) to the developer. The power of the city government is a systemic power that shapes the process of coalition building within the dilemmatic process of making regulations and public policies.
\end{abstract}

Keywords: Urban growth machine, developer, city governments, the policy dilemma

\section{Introduction}

The analysis of urban economic and political development has situated the city as an essential growth machine since 1970 (Molotch,1976). The growth machine theory assumes elite groups control that urban growth with land-based interests. The elite is the political elite represented by the city government and the economic elite represented by private developers/investors. To realize this interest, they have converted the land into a property that has added value. This kind of situation can occur with coalitions woven by city

Correspondence: Siti Aminah

Department of Political Science, FISIP Airlangga University, Surabaya

E-mail: siti.aminah@fisip.unair.ac.id governments and developers (Logan, 1987).

Along with socio-economic and political changes, cities are not only a growth machine but also have impacts and problems for social ecology and ecology itself. The Surabaya city government (Pemkot Surabaya) runs a coalition with the private sector (developer/ investor). Based on BPS 2016 data, the area of Surabaya in 2016 was $326.81 \mathrm{~km} 2$ and the population until the end of August 2017 was 3.057.766 people (Dispendukcapil Surabaya) (BPS, 2016).

Infrastructure development, both housing, factories and social facilities are all intended to serve the needs of the population. Therefore, changing land use is a problem that arises from the coalition. Fertile agricultural lands have shrunk in the past four years to 300 hectares 
with changes in agricultural land use to roads and housing (Putra, 2016).

These lands have turned into real estates, apartments, and commercial public spaces (such as plazas and malls). Which means development is in a policy dilemma. Development does not always run within the corridors of spatial regulation; thus, changes in land use mean changes in spatial aspects that lead to a not pro-ecological development. The ecological crisis can trigger conflict between the community and the community, the community and the investors, the community and the government, and it can even trigger conflict among governments. That happened between Batu City and Malang City (n.n, 2017). The city faces several problems such as traffic congestion, a land conversion that causes flooding in the rainy season, and the problem of garbage and pollution since 2013 (abouturban, 2016).

The development of the cities in the West and East Surabaya is immensely rapid, resulting in many land use changes. In East Surabaya which has 1.252.101.121 $\mathrm{m}^{2}$ area with $30.224 .700 .82 \mathrm{~m}^{2}$ land use area change by $0.3244 \mathrm{~m}^{2}$. Significant changes in land use occur from the fish hatchery to the asphalt road and rice fields, vacant land, freshwater ponds, densely populated to luxury settlements, trade services (BPS, 2015). Many developers are waiting in line to get a building permit from the Surabaya city government to build apartments, shop house, and malls. ${ }^{1}$ That happened because the Surabaya city government built the Surabaya Outer Ring Road (SORR) along 19.8 kilometers targeted for completion in 2018.

This context cannot separate from the conflicting interest between government elites and economic elites (developers/investors) and society versus society. Conflicts about land and spatial planning are understood as an area to express the interests of several land-based political and economic elites. Economic elites who act as developers and investors intensify land by buying land owned by residents to further coalition with Surabaya city government to acquire land.

Land acquisition for infrastructure development and settlements, trade, industrial/service areas are not in contradiction with the city government development policy in the Surabaya City Spatial Plan 2014-2034. Political and economic elite shares interests above its land/soil. The competition happens amongst the financial elites who control the land with elites who control other areas, and so do the people who have rice fields. Private investors/developers own land ownership in Surabaya. The rapid development in Surabaya then caused problems in the environmental and social aspects. Environmental issues are not merely a consequence of increasing population and intensification of industrial technology, but also because of industrial expansion which creates new trade/business areas.

How can the government run the urban growth machine (urban system) to build cities while overcoming the current social-ecological crisis? Hypothetically, the government faces policy dilemma, to consistently overcoming the social ecology problem or to orient development policies on urban growth. Therefore, the Surabaya city government is in coalition with the private sector that has capital. City government gave private sector permission to manage the land based on a sustainable development policy arrangement. Thus, the lands undergo usage change. Two parts in East and West Surabaya became the focus of this land management practices which caused land disputes or conflicts to arise between communities and investors as well as between communities and the government during the process. Development by private developers/ investors in the form of independent cities.

The development of an independent city is part of the economic development policies and to implement the policy requires large amounts of land. There are state-owned land and public land that does not belong to the state. There is also land leased by the state to third parties. Competition between landowners and the land tenant is getting tougher. Rental prices are getting higher because of the availability of land is increasingly limited. As a result, local government and within the government bureaucracy itself are in a land use configuration where the local government is the dominant actor.

\footnotetext{
${ }^{1}$ Interview with an informant from Surabaya City's Head of the Department of Public Housing and Settlement Area (DKPRKP CKTR), 2017
} 
Urban development problem lies in land use. City government and developers carried out land acquisition for infrastructure development. Therefore, government leaders at the local level (political elites) try to legitimize themselves as promoters of urban development to perform the urban development policy agenda that refers to the concept of sustainable development. City construction continuously expanded until it becomes a project of accumulation of local areas/cities, Tien Hsing (2010) mentions this phenomenon as industrial modernity. While Elkin, McLaren, and Hilman (1991) stated that urban planners, politicians, communities, face the challenges of sustainable development within the context of urban development. Besides, how city governments (urban systems) overcome the ecological and socio-ecological crisis. Murray Bookchin (1986) analyses the need to include a social perspective in the analysis of ecological crisis which happened because of development.

There is a propensity for interaction between development actors, namely the difficulty to translate the rhetoric of sustainable development into action. There are demands on cities regarding their resources and their impact on the global and local environment, in-depth analysis on the patterns and forms of development, providing green spaces and conservation, as well with transportation, waste, and pollution systems.

It is important to situate the urban environmental problems in the socio-economic context in urban development and to sketch out potential conflict resolution possibilities between the purpose of maintaining and preserving the environment and the goal of creating economic growth. Another thing is to identify and discuss the development policies and practices performed by the city government to become more environmentally friendly and provide a healthier, more just, and comfortable living places for the residents of the city.

\section{Research Method}

This study uses qualitative methods, a contextual study that situates researchers as instruments and adapted to the existing conditions. This study took place in Surabaya City. The reason behind it was of its rapid growth, and the construction of urban facilities and infrastructure involves many local, national, and international investors. Surabaya City has several independent cities which are a form of urban expansion and located towards the outskirts of Surabaya, in terms of geography. Construction of independent city needs land, and the government faces a problem in procuring land required by investors or developers.

The research location is the eastern part of Surabaya City, represented by (district) Mulyosari and Sukolilo and the western part of Surabaya represented by Sambikerep and Lakarsantri. Collected data were analyzed through qualitative techniques with a desk review (the study of documents, statistical data, prior research, and textbooks). In-depth interviews were conducted with individuals representing the city government (investors/ developers bought head of the district and district secretary, developers and community whose land (fields) and houses).

We also carry direct observation by paying attention to productive agricultural areas that change function into settlements, apartments, exchanges, and trade services. The developer has brought rapid development of infrastructure and independent city housing. Observations on the ground were carried out with changes in community space and settlements and land controlled by the community but had become the target of the project developers. All data are interpreted using the theoretical framework used in the study, further narrated into sentences. While data from direct observations is described for the needs of data analysis and discussed through the theory used.

\section{Surabaya City Development}

A study in factors regarding land use change (functional shift) conducted by Junaidi (2016) focused on fish hatchery into housing in Wonorejo, Rungkut, Surabaya. His findings show that the process of land conversion from a fish hatchery to house and sustainable livelihood strategies from fish farmers who have sold their fish hatchery to developers. That happened since 2002. Changes in the fish hatchery land use are part of the natural impact because of the development and its span that occur from Surabaya City. One of its development factors is the interaction between 
the core cities with the satellite cities (suburban).

Fish farmers still depend on managing other farms for a living. While the research from Jelita C. Jihan (2014) shows the conformity of land use with the spatial plans, showing $22.444 .205,3 \mathrm{~m} 2(74.26 \%)$ area of land use is under the planned regional function development, and an area of 7052.911,412 $\mathrm{m} 2(23.33 \%)$ land use is not under the planned regional function development while the other $727.584,1 \mathrm{~m} 2(2.41 \%)$ used for rivers and roads.

The change in land use shows that the city government has used the urban growth machine for city development centered on the eastern and western parts. This is due to the fact that the eastern and western parts associated with the construction of the Middle East Ring Road (MERR) in the eastern part of Surabaya, hence it is considered capable of bringing an impact on the increase in the value of investments, especially property products. ${ }^{2}$

While in the western part of Surabaya there is an infrastructure of the Outer West Ring Road (JLLB) that connects Lamong Bay with the South Surabaya area. Both regions are two potential growth poles and become the mainstay of the city of Surabaya. The two parts of the region have characteristics as regions with sharp levels of disparity between rich and poor. Economic business activities move to the eastern and western regions of Surabaya. The two regions became the regions that became the incentives for developers and investors for development.

In West and East Surabaya, there are two large developers and investors (PT Pakuwon Jati and PT Citra Surya Tbk) who build housing and physical facilities (roads, hospitals) and social facilities (education, health). The development is managed by two large developers and investors who have built warehousing complexes in the suburbs. This raises environmental and social degradation problems. We used the participatory research approach in studying the case. Surabaya city government carry out the construction of the
JLBB along with eight developer companies with $80 \%$ portion worked by the developer. They expect JLLB to reduce vehicle flow loads that centered in the downtown (Hafiyyan, 2015).

JLBB construction was designed in 1990, several developers/investors helped finance the development, so that some developers, one of which is PT Citra Surya, filed a location permit to develop the Surabaya CitraLand project. The idea came when Surabaya was redesigning its urban planning. ${ }^{3}$ Developers contribute $50 \%$ of the total $80 \%$ JLBB infrastructure, notably PT Ciputra Surya Tbk. The western part will grow into a new city center. PT Ciputra Surya Tbk fixes the 2,000-hectare Surabaya Citraland spatial project to become the Singapore of Surabaya. ${ }^{2}$

Independent city development, carried out by developers, contains problems that reduce the legitimacy of the city government. However, during an interview with informants, it is revealed that the city government itself also needs developers for the purpose of city growth. Hence, granting land management license would have the power to force for Surabaya government. There are two problems where situates the community in the politics of struggle. First, retain their property rights, by forced evictions, along with inadequate money compensation or housing compensation. This is a manifestation of a city development project. The second is non-confrontational nonpolitical problems. They withdraw ownership of community land along the outskirts of the city as part of the development project area. Those lands then turned into apartments and social facilities development center. This brings advantage to investors/developers by selling their property to the public.

Sustainable development has received the attention of the Surabaya government, which can be seen from various policy products, the results of which are parks, green open spaces (RTH) that reach $20 \%$ of the total area of Surabaya. Both private open space, public open space, urban forest, forested coastal

\footnotetext{
2 Jalan MERR dibangun, kawasan Surabaya Timur dibidik jadi Central Business Distric. (2018). Retrieved from http://jatim.tribunnews.com/2018/10/01/jalan-merr-dibangun-kawasan-surabaya-timur-dibidik-jadi-central-business-distric-baru

${ }^{3}$ Opinion from the President Director of PT Ciputra Surya Tbk, Retrieved from https://ekonomi.bisnis.com/ read/20150925/47/475773/pengembangan-kawasan-surabaya-barat-makin-pesat, accessed March 3, 2017.
} 
areas, urban forest areas, nature conservation areas, coastal borders and parks present along the city center and suburbs of Surabaya exhibits the green city concept implementation as well as the form of urban space restructuring. Mentioned in the Spatial Plans (RTRW) No.12 of 2014 concerning the 2014-2034 Surabaya City Area Spatial Plans.

\section{Urban Growth Machine Coalition}

The presence of large private investors in the construction of East Surabaya and East Surabaya was also carried out by Intiland Development and Puncak Group. This developer has contributed to East Surabaya as a region which accounts for the most significant property supply, $47 \%$. Then followed by West Surabaya (36\%), and 5,000 apartment units in Central and South Surabaya. The development of an independent city using the concept of sustainable development is an example of the use of a social ecology perspective that integrated with the concept of urban growth machines and city development government. Integration of the three perspectives would comprehensively describe the realities observed. How does the city government (Pemkot) carry out economic development by making the city a growth machine? The construction of physical infrastructure and social infrastructure is a mosaic of the interaction of interests between actors who play a role in urban development and land use patterns.

This study also re-examines what Harvey Molotch (1976) had done with a political economy approach which able to explain the tendency of cities to grow rapidly as a realization of a relationship between political and economic interests. Coalitions between political elites (government) and economic elites (developers) are the machines of urban growth, therefore no city government avoids substantive arguments as stated by Molotch that the work of the urban growth machine contains empirical substances from practices carried out by city governments (urban systems) to build cities to meet the needs of the population. Therefore, the city government is a machine of growth.

Running the machine of growth for the Surabaya City Government faces the impact of land use based on functions. This study found several cases that explained the policy dilemma faced by the City Government when investors/developers needed land to build infrastructure and settlements intended for the upper middle class. The construction of new cities or independent cities in the western and eastern regions of Surabaya led to conflict between citizens and investors. The case of Sepat Reservoir in West Surabaya is a problem that arises as a result of a coalition of municipal governments with developers/investors (PT Ciputra Surya. Tbk). Resident faces investors because they are protesting against investors' wish to backfilling the reservoir, in which according to the resident, it can damage the function of the reservoir's environment.

The problem of Sepat Reservoir is a reservoir of around 66,750 m2 in RW 03 and RW 05 in Sepat, Lidah Kulon, Lakarsantri. The case of Sakti Sepat Reservoir began with the Surabaya Mayor Decree No. 188.45/366/436.1.2/2008 which issued the land to PT Ciputra Surya, Tbk. as part of the exchange between the Surabaya City Government and PT Ciputra Surya, Tbk under the Joint Agreement Number 593/2423/436.3.2/2009 and Number 031/SY/ sm/LAND-CPS/VI-09, dated June 4, 2009. This policy is an exchange as part of Surabaya Sports Center (SSC) construction in Pakal. The Certificate of Rights to Build (HGB) issued after the exchange declared the land as 'yardland,' even though until now, the area still functions as a reservoir. ${ }^{4}$ In addition, most of the residents reject the backfill carried out by the developer because the reservoir has social and cultural values. In terms of the function of the reservoirs in Surabaya, particularly in Lakarsantri, it is an area that must be protected (as an aspect of social ecology). The existence of the reservoir has become part of the irrigation system which has been used by residents to overcome floods and droughts for the surrounding agriculture.

The growth machine coalition with developers has transformed productive agricultural lands both farms, fields and houses into the property business area, owned by large investors. PT Ciputra Surya Tbk manages most of the land use transfers. As of June 2015, the record shows that they have mastered 5,325 hectares of land in urban areas; residents previously owned

${ }^{4}$ Interview with Head of Lakarsantri Sub-district, May 2017. 
these lands. Pakuwon Group also controls around 330 hectares for the development of Grand Pakuwon West Surabaya housing estate. While Sinarmas controls 120 hectares in Bukit Mas I and II housing development. These property ruling group take controls in manipulative ways, even using intimidating and repressive methods. Take a look at Sepat, the residents oppose the city government and private investors, and this also happened in several other reservoir cases; therefore these become the basis of argumentation in presenting the premise of manipulative, intimidating and repressive methods of control.

What happened in Surabaya applies to the thesis put forward by Stone (1993). The city government has the capacity to run a government that is not easily understood and perceptible through the electoral process. Government capacity is created and maintained by combining coalition partners with appropriate resources, notably with non-government actors and other parties (private/investors and communities). If a government coalition has to work, it must be able to mobilize resources commensurate with its main policy agenda. This is the main proposition of the Theory of Growth; what is carried out by the government can be used when a government faces difficulties in carrying out development policies in its jurisdiction.

There are certain types of resources needed by the government, besides political leadership. According to Stone political leadership is a creative exercise of political choice, which involves the ability to develop arrangements in which it can mobilize resources, thus enabling people to achieve strenuous and unusual goals. In short, Urban Governance Theory describes the concept of government originating from a political economy perspective that rejects the pluralist assumption that government authority suffices to make and implement policies, as well as structuralist assumptions that economic forces determine policy. Government analysis in Stone's view can explore the middle ground between conceptualizing government as an organism that mediates between causal variables in the environment and policy outcomes. Although the government represents a path where local actors reconcile external pressures such as economic change, the focus in government analysis is the internal dynamics of coalition formation, on civic cooperation or informal ways of coordination across institutional boundaries. The socialecological approach (Laurent, 2015) aims at overcoming this knowledge gap by considering the interrelationships between social and environmental problems, showing how social logic determines environmental damage and crisis and explores reciprocal relationships, the consequences of this damage to social inequality.

Rodgers, S. (2009) says urban growth machines is a thesis that influences urban politics where urban growth unites pluralistic interests in relations to cities. In the city growth, place commodification transpires where the place understood as a land of social and economic value. There are three aspects in understanding the commodification of places, the coalition between actors and organizations (growth machines), sharing of interests in local growth which then impacts on land values, and competition for growth machines aimed at mobile capital investment, which concurrently aims to win public support for urban growth.

Five concepts need to be underlined in urban growth (Rodgers, 2009), those are the use of value and exchange of value with the place; place entrepreneurs; the machine of growth and fellowship; competition for moving capital; and promote growth as a public need. In exchange for place value, the growth machine thesis not only evaluates the place for its existence as a place of survival but as an impact of human social activities where money circulates from a land which is then realized in the form of real estate as a basis for daily social activities. So that it interprets the exchange of values as a product of centralized activities from various actors to make money from real estate.

The most influential factors in urban growth machines are place entrepreneurs. Rodgers (2009) mentions that there are three types of place entrepreneurs. First, basically passive place entrepreneurs or traditional rentier who act as landowners. They work simply by collecting land and then renting or selling their land. Second, the more active place entrepreneurs involved to buy and sell land, predict and estimate changes in land values, and create profits by buying and selling strategic real estate. Third, most active and most important place entrepreneurs or structural speculators. As landowners who 
not only estimate the value of land, but also intervene in decision-making, arrangements, and investments they can control. They create good condition and relationship to increase the value of their land. This third type of land entrepreneur has a complex organizational body and specifically has targets to influence relevant policymakers. Among governments, entrepreneurs (land entrepreneurs), and the public, land entrepreneurs are seen as core figures of a growing coalition that can take on roles as property investors, developers, financiers, and so on.

This study sees a complex and important reciprocal relationship between social inequality, ecological crisis and degradation in social-ecological relations that have occurred in the city of Surabaya. East and West Surabaya areas development worsened the crisis and degradation. The research team found several impacts because of the massive expansion of machine growth, including (1) indifference to unsustainable land management, particularly from city governments as the main actors of regulators and policymakers. (2) A gap between the rich and poor. (3) the increasing growth of the urban poor because of changes in the livelihoods of farmers (fish hatchery owners/ fish farmers) and vegetable farmers and land release to investors. (4) Land ownership by the developer has the potential to cause disputes and friction between the community and the developer and the community with the Surabaya city government. This impact is evidence that development that provides a pressure point for the realization of urban growth causes losses to the community in a socio-cultural way, even disrupting the existing social ecology.

The logic of city growth is the logic of capitalism. So that the development carried out with the Surabaya City Government leads to the commodification of land that has been converted into property. Development is not always in line with people's welfare. In Setyawan's understanding, the development in Surabaya is an actual example of capitalism contradiction (Setyawan, n.d). This study proves that urban development that relies on the power of the government as a political elite that with their authority to make (public) policies becomes less powerful when dealing with the power of developers who have the capital and other important resources. Therefore, ecological problems arise from social issues. As far as the developer controls the capital, there will always be land use conversion, and there is a change in land ownership, there is the commodification of land. This, in turn, bring about social repercussions in the form of disputes or social conflicts and creates environmental crises and social and natural disasters such as floods, lack of clean water supplies, and so on. Within the perspective of social ecology, development should focus on the needs of human life and its ecosystem. Human ability is built to function as a moral agent to reduce unnecessary suffering from the development process.

Figure 5. Surabaya City Map

Source: http://pn-surabayakota.go.id/wilayahyurisdiksi/

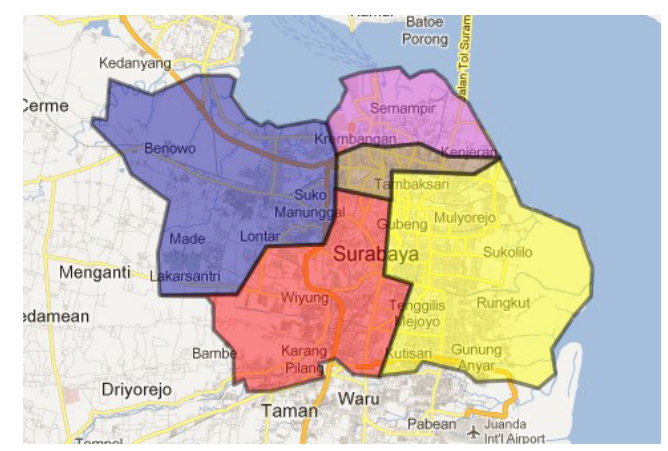

Two parts of Surabaya became a center for trade and real estate, and those are West Surabaya and East Surabaya. West Surabaya became a place in which the project of PT Ciputra Group developed, and East Surabaya is to be a mega project developed by PT Pakuwon Jati. West Surabaya is renowned to the public as a modern and commercial area because of Citraland. West Surabaya becomes a densely populated area and attracted many entrepreneurs.

According to Omar Ishananto: "before developers and investors interfere in urban development, this is an unproductive and useless area, but taxes on land, electricity and water charges are high, so land prices are also high. West Surabaya was once known as a backward suburban area with a high cost of living, making residents shunned this area. ${ }^{5}$ Nowadays the growth in West Surabaya can attract investors and residents from various regions to flock to migrate to this suburb. Only entrepreneurs can pay high taxes and levies, so the Surabaya City government supports the development.

\footnotetext{
${ }^{5}$ http://bantuanhukumsby.or.id/2016/05/11/ waduk-sepat-menggugat-walikota-ketua-
} 
Chart 1. Impact of the Growth Machine Practices on City's Social Ecology

Identification of the Impact of the Coalition on Social Ecology Aspects in Surabaya

Tanjung Sari
(Sukomanunggal, West
Surabaya)
1. A land takeover by
the Surabaya City
government.

2. The City Government uses over 2 hectares of residents' land for the Satpol PP confiscated warehouses.

3. City Government installs a sign (signpost) that reads "Surabaya Government Assets."

4. The land belongs to the residents as proven by Proof of Ownership letter in the form of Petok D No. 184 made since 1952.

Keputih (Sukolilo, Surabaya
East)
East)

1. Seizure of land/ fields from residents (120 families) by the developer.

2. Developers (PT Pakuwon Jati) claim land in Keputih Pompa because it is the owner of a land plot of $38,322 \mathrm{~m}^{2}$ in 2004 (Freehold Title/SHM) and including the land occupied by residents along the riverbank.

3. Around 1992 pedicab drivers, beggars, homeless people, scavengers were given free land to live in. Based on recognition from the residents, they obtained land for the house from the past Mayor. It is recorded that there are around 23 heads of families (KK) who live in a place that is now claimed by the Surabaya City Government (Pemkot).

4. Residents who live along the riverbank have evidence that the land belongs to the Department of Water Resources of East Java.
Lidah Kulon (Lakarsantri, West Surabaya)

1. The Sepat Reservoir dispute involves a conflict of interest between residents and developers (PT Ciputra Surya Tbk.), and the city government since 2008.

2. The Mayor of Surabaya and the Chairperson of the Surabaya city legislative council (DPRD) have not yet revoked the Mayor Decree Number 188.451.366/436.1.2/2008 concerning "Transfer by Exchange of Assets to Surabaya City Government Assets in form of Ex-Land.

Allotment (Ganjaran/ Bondo Desa) in Beringin, Lakarsantri; Jeruk, Lakarsantri; Babat Jerawat, Pakal, Surabaya. With Land Owned by PT. Ciputra Surya ". 6

3. On May 11, 2016, residents of Dukuh Sepat, Lidah Kulon, made litigation efforts by filing a citizen lawsuit (CLS) to the Mayor of Surabaya and the Chairperson of the Surabaya city legislative council in Surabaya District Court.

4. In the Building Rights Title (HGB), issued after the swap, the Sepat Reservoir area is declared as "yard land", whereas until now, the area still functions as a reservoir. 
Behind the progress of development in West Surabaya, lies injustice between entrepreneurs and the community. The land on which these magnificent buildings are built was bought from the community at low prices and sold by developers as housing and offices at prices that landowners cannot reach first. So that every citizen who gives up their land, they will be excluded from the city's growth because the price of the land has increased over time. Besides social inequality, urban growth leaves an unavoidable ecological impact, namely, floods.

West Surabaya comprises of (sub-district) Benowo, Pakal, Asemrowo, Sukomanunggal, Tandes, Sambikerep, Lakarsantri. Inaccordance to Peraturan Daerah Kota Surabaya Nomor 3 Tahun 2007 tentang RTRW Kota Surabaya Pasal 18 ayat (3) Unit Pengembangan VIII (Local Regulations on spatial plans) Dukuh Pakis and Sukomanunggal are designated as residential areas, trade, services, and special areas.

The Special Area is defined as an area with special conditions and characteristics because the types of activities accommodated have certain conditions and treatments such as military areas, strategic industrial areas, and port areas. The X Development Unit comprising Lakarsantri, Wiyung, and Karang Pilang are designated as residential, educational, industrial and conservation areas. The XII Development Unit which comprises Sambikerep and Pakal is designated as residential areas, trade and services, and conservation.

The East Surabaya area comprises Gubeng, Gunung Anyar, Sukolilo, Tambaksari, Mulyorejo, Rungkut, and Tenggilis Mejoyo. Similar to PT Citra Sura, PT Pakuwon Jati has also changed the face of the East Surabaya region into the central business district. PT Pakuwon Jati's construction projects in Surabaya include Pakuwon City, Pakuwon Trade Centre, Laguna real estates (now Pakuwon City), and Tunjungan Plaza with the newest project in the form of TP 6 Office Tower. Mulyorejo and Sukolilo are Development Units II designated as residential, trading, education and conservation areas, as well as Green Open Space.

The Surabaya City growth model shows that land entrepreneurs dominate the growth coalition who takes an active and important role in urban growth. These land entrepreneurs can influence policymakers and the direction of city development. The case TP 6 in the Tunjungan UP VI Region prove this dominance while demonstrating that the growth of the city unites plural interests. The concept of the 55-storey or \pm 200-meter Tunjungan Plaza superblock project that offers grandeur and luxury is a building concept designed by Pakuwon Group. Pakuwon's interest is to seek profits by providing products that suit modern lifestyles. This $38.000 \mathrm{~m} 2$ project area is to be sold and leased, each of $23.000 \mathrm{~m} 2$ and $15.000 \mathrm{~m} 2$ wide (Hutauruk, 2017). On the other hand, the Surabaya City government needs to carry out regional autonomy and having the motivation to participate in the interurban competition development, this eventually became an opportunity for PT Pakuwon as a developer, originally named Laguna, to offer a development project to make Surabaya the only city in the East that has a skyscraper. Coupled with today's society lifestyles that craves luxury and grandeur.

Pakuwon City is residential with concept as an independent city in East Surabaya. Independent City is a residential area designed and developed with special functions related to the potential of the housing area. Pakuwon City as an independent city will not only include housing, but it is also equipped with educational, recreational, culinary and shopping centers. Easier access is available to residents, and they can access this housing from two lines, Mulyosari - ITS and Kenjeran. Both routes connect Pakuwon City to JI Dr. Ir. H. Soekarno or better known as MERR (Middle East Ring Road).

At the same time, Regional Regulation number 3 of 2007 concerning the Surabaya City Spatial Planning Article 22 paragraph (3) letter b (an Article from the Local Regulation on City Spatial Plans), states that the area around Juanda Airport is designated as a Flight Operational Safety Zone (KKOP), it is located in UP (Unit Pembangunan/Development Unit) I Rungkut, UP II Kertajaya, UP VII Wonokromo, some areas of UP IV Dharmahusada, UP VI Tunjungan, and UP X Wiyung. Letter c specifies the regional boundaries and the height limits of buildings and objects as referred to in Letter $b$ determined according to the applicable laws and regulations. Decree of the Minister of Transportation KM. 5 of 2004 concerning the Flight Operational Safety Zone (KKOP) in the vicinity of Juanda-Surabaya Airport (Ministerial Decree on Flight Operational Safety Zone in 
Juanda Airport Surabaya) become a reference in calculating building height limits, and set KKOP in the Tunjungan area as high as 150 $\mathrm{m}$, which means there should be no buildings with a height of over $150 \mathrm{~m}^{7}$ However, the Mayor of Surabaya submitted a request for revision of the KKOP regarding the building height limit to the Minister of Transportation to several Central Business Districts (CBD) with the urgency that the Surabaya City Area would not be possible to construct CBDs including horizontal housing, hence it needs vertical CBD. It is here that Pakuwon's dominance seems to be able to influence decision making.

Development in East Surabaya reaps a lot of disputes/conflicts. Conflict in the development of the Wonorejo Ecotourism Area, managed by Joko Suwondo, as a conservation area which was later used as ecotourism, caused crowd coupled with the presence of merchants. Ecotourism development requires logging of mangrove trees. Soni Mohson, entrepreneurs and mangrove cultivation activists explained that before ecotourism exist, mangrove trees were often logged and sold illegally, where the perpetrators received criminal sanctions. The logging of mangrove trees was legal for the benefit of ecotourism development, and its impact brings damage to the surrounding ecosystems. They are coupled with the construction of a jogging track with a solid frame which violates the rules. Because of ecotourism activities, birds rarely stop by during their immigration period, tourist boats also prompted in dead fish. The fish in the mangrove area is food sources and livelihoods of the people living nearby. Fishermen complained about this but received no response. The conversion of conservation into ecotourism means a change in place value, where it was once a place to preserve the ecosystem, it is now an economic-oriented place.

According to an informant, the conservation area is the East Coast of Surabaya (Pamurbaya) as stated in Regional Regulation 3 of 2007 concerning Surabaya City RTRW.
But the boundaries of the conservation area are not yet clear. In the socialization of Perda No. 3 of 2007 which he had attended, they explained that $25 \%$ of the conservation area is available for housing. However, the margins are never confirmed in Perda, even though the city government has stated a figure of $25 \%$ for housing. In fact, many houses have been built in the mangrove area and already hold a building permit (IMB) ${ }^{8}$

This lack of clarity did not receive a proper answer from Perda socialization officer, and our informant even criticized as "not reasonable to ask." In Wonorejo alone, development company owns $95 \%$ of the fish hatchery. ${ }^{9}$ Our informant further explained: "the District of Rungkut and Gunung Anyar are Development Units I, those two are designated as residential, educational, conservation, and industrial areas. At the same time, they designate it as a Land Protected Area that protects its subordinate areas. "Pasal 27 ayat (2) Regional Regulation 3/2007 concerning Surabaya City RTRW confirms that everyone is prohibited from carrying out development activities or land use that can cause environmental damage to protected areas. Article No. 20 section (2) of that local regulation said the development of the Zone IV marine area comprises the coast and the East Sea with the main function of conservation and rehabilitation of the marine and coastal environment as well as fishing and aquaculture areas. Surabaya city government did not properly understand the irregularities in mangrove are utilization within the corridors of conservation. Besides residential buildings in the mangrove area, there is also a construction of board bridge with concrete poles in the mangrove ecotourism location.

\section{Environmental Development Innovation}

Urban Growth Machine in the era of capitalism has led to continued social problems.

\footnotetext{
7 www.jawapos.com/baca/artikel/1383/kemenhub-minta-daftar-cbd (May 22, 2014) accessed September 21, 2017 at 09:30 PM

${ }^{8}$ Interview with an informantion, the coordinator of Kelompok Tani Mangrove Wonorejo (association of farmers), in May 2017.

${ }^{9}$ The mangrove conservation area in the east coast of Surabaya (Pamurbaya) has been designated as a protected area since 2007 through Perda No. 3 of 2007 concerning the Spatial and Regional Plan (RTRW) of Surabaya.
} 
Competition is tight between cities and between municipal governments. That is a context that spurs the emergence of an urban growth machine coalition. The ecological crisis, the expansion of the residential-industrial area, and losing land/settlements of specific community groups are consequences of social ecology aspects that have not received government attention in the formulation of development policies. Land and buildings in Surabaya are no longer usual commodities but are commodities from the city's growth machine.

Elite from city governments and developers/ investors seek to create economic growth in an area called the independent city. This is a government policy dilemma in decision making. Coalitions and dilemmatic conditions can be changed but depend on the existing sociopolitical context, targets, and orientation of the city government, besides the growth ideology which is the potential strength of the growth machine. Thus, Surabaya's development that mainly concentrates in western and eastern parts ignores social ecology aspects. Development is not only less human because in the process of land use changes comes social dispute that neglects socio-cultural needs of the community. This can be seen in Chart 2 .

Chart 2. Contestation of Changes in Land Use and Land Tenure in Development in Surabaya

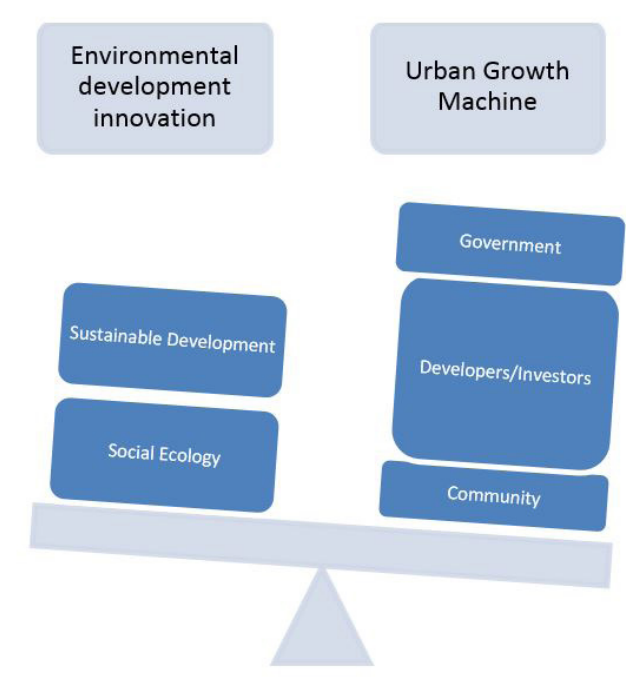

The chart above illustrates a coalition between political elites and economic elites who work together to create a consensus on urban growth. For the Surabaya City Government, the coalition is important, because the City Government are obliged to build cities together with communities and the private sector to meet the needs of the community. But the results of the coalition took the form of positive and negative impacts on the community. Environmental development innovations become not fully realized. Because the development of an independent city occurs through a process of land use changing.

Changes in land functions have transformed rice fields, reservoirs, fish hatchery into properties only middle and upper-class community can access. While the poor who was fish farmers and people who utilize the city government's land were evicted, their interest was put aside. Surabaya's city growth and economic business development that are in the top priority of the city government. These unfortunates people, the victims of evictions, cannot fight development that is not on their side. Coalitions between city government and developers are a coalition that attaches the value of the land to produce new growth centers that benefit the developer.

Development that relies on growth machine raises the ecological risks borne by the urban poor. Because the government who holds power and authority does not act to protect the interests of the urban poor whose land was bought by the developer. The process of impoverishment behind city growth is another impact of the coalition's practice. Therefore, it is important to redefine cities and their citizens in the language of social ecology. Hoping that social and environmentally sound development will be capable of preventing or even minimizing the existing urban crisis. Because with the continually increasing population migration from village to city, the threat is not only limited to geographical but dehumanizing city life. This dehumanization can destroy the community and the denaturation of agricultural life in the suburbs of Surabaya.

Investors enjoy the benefits of intensifying land use in their area (land that has been built with various social facilities, roads, housing, etc.). Political elites and economic elites compete with other land-based elites to have growthtriggering resources within their territory and not others. East Surabaya and West Surabaya are racing to build independent cities as demanded by the upper middle class. Independent cities built by developers provide many benefits with educational facilities, trade, offices, housing and public spaces that are better than public housing. 
Figure 1. Citraland luxury housing entrance. Source:http://rumahcom-asli.blogspot.com/2011/04/ citraland-surabaya-kebanggaan-ciputra.html

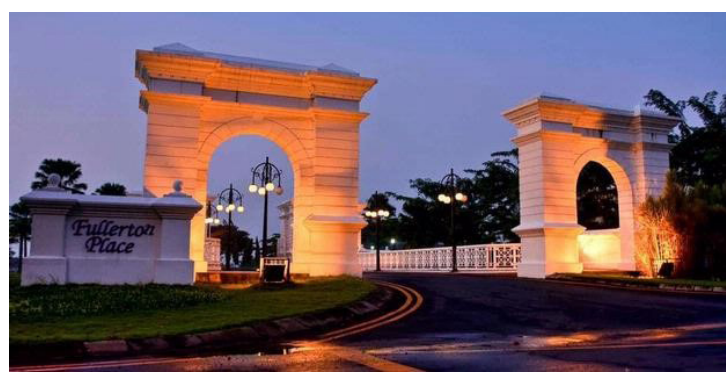

Figure 2. Citraland luxury housing entrance. Source:http://rumahcom-asli.blogspot.com/2011/04/ citraland-surabaya-kebanggaan-ciputra.html

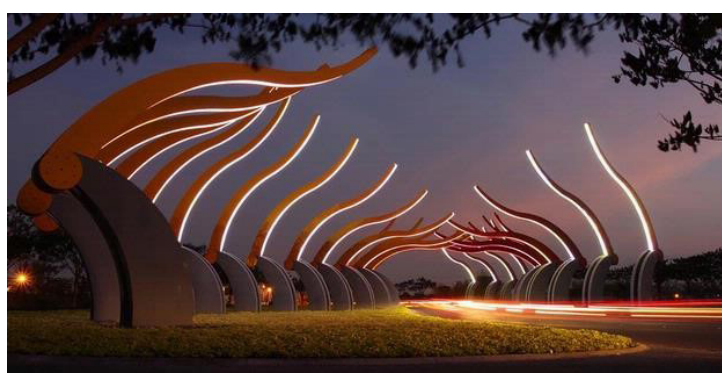

Figure 3. Scene in one of the streets in Pakuwon City housing block.

Source: http://www.wibowo.co/pakuwon-city/

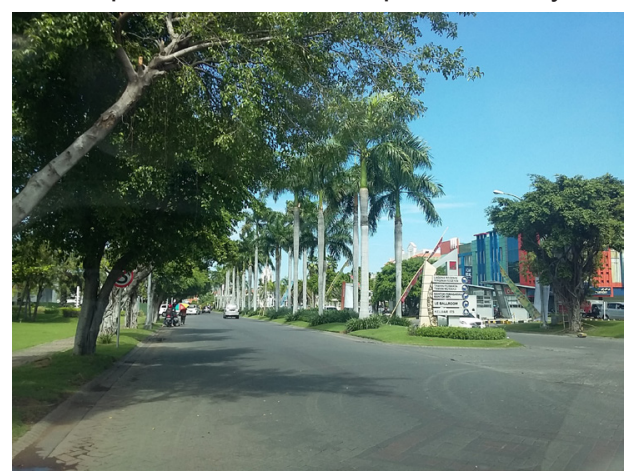

Figure 4. A view from one of Pakuwon City housing block.

Source: (https://www.brighton.co.id/cari-propertisurabaya/view/-Pakuwon-City-).

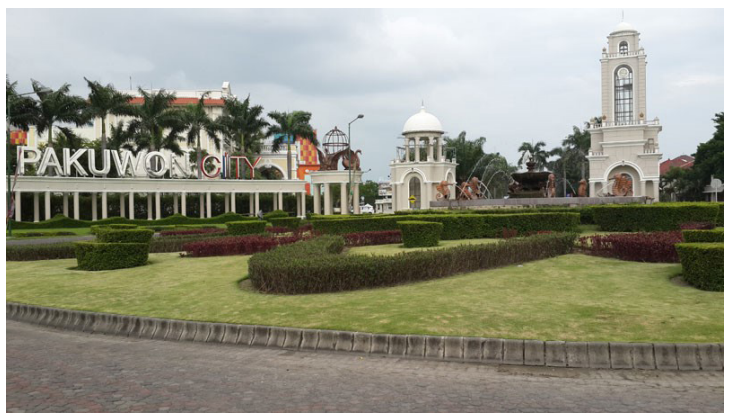

\section{Conclusion}

Surabaya developmentfaced various obstacles. Problems in ecology and social consequences of development are part of policy dilemma indicators. Sustainable development only makes discourse that does not pay attention to the contextual aspects and characteristics of the egalitarian city of Surabaya. Instead, the development has made access easier for developers and reduce the involvement of city government. When the community faces the growth machine in the struggle for a living space, it creates the polarisation of the growth coalition and the anti-machine coalition when environmental degradation occurs. Over time, this condition continues, and as if there is an omission, the city government seems to give space for developers in developing the city, which is part of the urban growth machine and urban government.

To address potential anti-growth group concerns, the land-based elite will take indirect actions about project development before it develops into formal opposition; dan 3) the landbased elite, from time to time, will voluntarily develop a variety of objectives that reduce their pursuit of a series of profit-oriented goals.

The rapid growth of independent cities tends to benefit the developers in using space to have economic value on the land they manage (according to modern urban settings). Social ecology approach might reduce and control the growth machine, as well as policy considerations for urban government. In making city development policies, the city government must be independent, building infrastructures that reduce the growth of the urban poor. Finally, it needs to involve the community in the growth coalition, and it is required to create a built-in environmental innovation that involves all parties without taking over land and caused environmental degradation. This means the pressure point of the growth coalition needs to be altered from the land-based interest elites (investors, developers, and government) to social ecology-oriented elites

\section{Acknowledgment}

We would like to thank Reza Maulana Hikam dan A. Faricha Mantika for helping with the translation. 


\section{References}

Bookchin, Murray. (1986).“Ecology and Revolutionary Thought" in Post Scarcity Anarchism. Montreal: Black Rose Books. p. 80.

Data from Surabaya City Statistics Bureau (BPS) 2015

Data from Surabaya City Statistics Bureau (BPS) 2016

Elkin, Timothy, Duncan McLaren, Mayer Hilman. (1991). Reviving the City: Towards Sustainable Urban Development. UK: Continuum International Pub.

Jihan, Jelita C . (2014), Analisa Zona Perubahan Penggunaan Lahan Di Kecamatan Sukolilo Surabaya Timur Berbasis SIG,thesis, ITS, Surabaya. http:// repository.its.ac.id/59674/1/3511201204Undergraduate\%20thesis.Pdf

Junaidi, Muhammad. (2016). "Faktor-Faktor yang Menyebabkan Alih Fungsi Lahan dari Tambak Menjadi Perumahan di Kelurahan Wonorejo Kecamatan Rungkut Kota Surabaya, Swara Bhumi e-Journal Pendidikan Geografi FIS UNESA, Vol 3, No 3. (http://jurnalmahasiswa.unesa. ac.id/index.php/swara-bhumi/article/ view/17019)

Laurent, Eloi. (2015). Social-Ecology: Exploring the Missing Link in Sustainable Development, working paper, HAL Id: hal01136326, https://hal-sciencespo.archivesouvertes.fr/hal-01136326, accessed March 4, 2017

Logan, John R. Logan and Harvey Luskin Molotch (1987). Urban Fortunes: The Political Economy of Place, California: University of California Press.

Molotch, Harvey Luskin. (1976). "The City as a Growth Machine: Toward a Political Economy of Place", The American Journal of Sociology, Vol. 82, No. 2. (Sep., 1976), pp. 309-332. Stable URL: http://www.jstor. org/journals/ucpress.html, accessed June 3, 2017.

Rodgers, S. (2009) 'Urban Geography: Urban Growth Machine', in The International Encyclopedia of Human Geography. R. Kitchin and N. Thrift (eds.). Oxford: Elsevier. Volume 12: 40-45

Setyawan, Wahyu Eka. Pertahankan Waduk Sepat, Selamatkan Waduk Terakhir Kota Surabaya. Booklet Sepat Series 1 (https:// geotimes.co.id/accessed April 10, 2017 at 12.25 PM).
Stone, Clarence N. (1987). Summing Up: Urban Regimes, Development Policy, and Political Arrangements in The Politics of Urban Development, C. N. Stone and H. T. Sanders (eds.), 269-290. Lawrence: University Press of Kansas.

Tien Hsing, You. 2010. The Great Urban Transformation Politics of Land and Property in China, Oxford: Oxford Univ. Press.

\section{References from Media}

Hutauruk, Dina Mirayanti. (2017). Retrieved from Industri.kontan.co.id/news/pakuwonhidupkan-proyek-perkantoran (May 8, 2017) accessed September 21, 2017 at 12:30 PM.

www2.jawapos.com/baca/artikel/1383/ kemenhub-minta-daftar-cbd (May 22, 2014) accessed September 21, 2017 at 09:30 PM.

Putra, Yudha Manggala P. (2016). Retrieved from https://nasional.republika.co.id/ berita/nasional/daerah/o46sc0284/ lahan-pertanian-di-surabaya-menyusut, accessed August 25, 2017, at 11.35 AM.

Pembangunan d Tengah Penyeimbangan Ekologi. (2017). Retrieved from https:// news.detik.com/kolom/3661257/ pembangunan-di-tengah-penyeimbanganekologi, accessed August 24, 2017, at 09.25 AM.

Abouturban. (2016). Surabaya Kota dengan Masalah Sampah dan Polusi yang Masih Perlu Perhatian Khusus. Retrieved from www.abouturban.com/.../surabaya-kotadengan-masalah-sampah-dan-polusiyang-ma, accessed August 24, 2017 at 09.40 AM.

Jalan MERR dibangun, kawasan Surabaya Timur dibidik jadi Central Business Distric. (2018). Retrieved from http:// jatim.tribunnews.com/2018/10/01/jalanmerr-dibangun-kawasan-surabaya-timurdibidik-jadi-central-business-distric-baru, accessed April 5, 2017 at 10.10 AM.

Hafiyyan. (2015). Retrieved from ht t ps://ekonomi.bisnis.com/ read/20150925/47/475773/ pengembangan-kawasan-surabaya-baratmakin-pesat, accessed April 5, 2017.

http://bantuanhukumsby.or.id/2016/05/11/ waduk-sepat-menggugat-walikota-ketuaaccessed April 6, 2017 at 12.25 PM.

http://pn-surabayakota.go.id/wilayah- 
yurisdiksi/ accessed April 5, 2017 at 10.10 AM

https://www.intiland.com/id/abouts/milestones, accessed September 12, 2018. At 12.30 PM

http://rumahcom-asli.blogspot.com/2011/04/ citraland-surabaya-kebanggaan-ciputra. $\mathrm{html}$ accessed April 9, 2017 at 12.30 PM

http://www.wibowo.co/pakuwon-city/ accessed April 9, 2017 at $12.35 \mathrm{PM}$

https://www.brighton.co.id/cari-propertisurabaya/view/-Pakuwon-City / accessed April 9, 2017 at 12.35 PM

\section{Legislations}

UU No. 23 Tahun 2014 tentang Pemerintah Daerah (Law on local government)

Peraturan Daerah Kota Surabaya No. 3 Tahun 2007 tentang Rencana Tata Ruang Wilayah (Law of Spatial Plans, 2007)

Peraturan Daerah Kota Surabaya No. 12 Tahun 2014 tentang Rencana Tata Ruang Wilayah (Law on Spatial Plans, 2014) 